\title{
Anti-inflammatory screening of ethanolic leaf extract of Vernonia arborea Buch. -Ham.in formalin induced albino wistar rats
}

\author{
Sriram Sridharan ${ }^{*}$, Meenaa Venkatramaniं ${ }^{2}$, Kavitha Janakiraman², Brindha Pemiah ${ }^{1}$ Sasi kumar \\ Chinnagounder ${ }^{2}$
}

${ }^{1}$ Centre for Advanced Research in Indian System of Medicine (CARISM), SASTRA University, Thanjavur 613 401, Tamil Nadu, INDIA. ${ }^{2}$ Post Graduate and Research Department of Biotechnology, Nehru Memorial College (Autonomous), Puthanampatti, Tiruchirappalli, Tamil Nadu, INDIA.

\begin{abstract}
Context: The therapeutic potential of the genus Vernonia has been well documented over the years. However the pharmacological potential of the plant Vernonia arborea (Asteraceae) has been relatively less explored. Objective: To investigate the antiinflammatory effect of the ethanol leaf extract of $V$. arborea against formalin induced inflammation in rats. Materials and methods: Formalin induced inflammation method was used to induce inflammation in rats. $0.1 \mathrm{ml} / \mathrm{kg}$ body weight (b.w.) of formalin was administered to the rats via sub-plantar injection to induce inflammation. The rats were pretreated with ethanol leaf extract of $V$. arborea at concentrations of 100, 200 and 300 $\mathrm{mg} / \mathrm{kg} \mathrm{b.w}$. once daily for 30 days. Indomethacin (25 mg/kg b.w.) was used as standard drug. Biochemical and hematological parameters along with levels of antioxidant enzymes were evaluated. Results: Administration of formalin reduced antioxidant enzyme levels, total RBC and $\mathrm{Hb}$. Pretreatment with ethanol leaf extract of $V$.arborea at dose dependent levels significantly increased $(p<0.05)$ the levels of the above parameters. A significant increase $(p<0.05)$ in paw thickness, level of serum enzymes (Aspartate transaminase, Alanine transaminase, Alkaline phosphatase and Creatine kinase), Lipid peroxide and leucocytes was observed in the rats induced with formalin, while these levels were normalized on pretreatment with ethanol leaf extract of V.arborea. Conclusion: The results of the present investigation demonstrate the antioxidant and anti-inflammatory potential of the ethanol leaf extract of V.arborea. However, it is imperative to isolate and purify the active principles involved in the pharmacological potency of this plant and determine its mechanism of action.
\end{abstract}

Key words: Vernonia arborea, formalin induced inflammation, indomethacin.

\section{INTRODUCTION}

Inflammation can be described as "the succession of changes which occurs in a living tissue and its reaction to injury of the living micro circulation and related tissues" that aims to perform the dual function of limiting damage and promoting tissue repair ${ }^{1}$ and are required for immune surveillance, optimal repair, and regeneration after injury. ${ }^{2}$ The cellular inflammatory process is a complex interplay between cells of the blood, blood vessels and cells of the injured tissue that involves a synchronized response of cells to an initial stimulus ${ }^{3}$ of mechanical, chemical or immunological stress, infection or injuries. The highly regulated sequence of events in an inflammatory response start with an initial production of pro-inflammatory mediators like kinins, prostaglandins and histamines that recruit professional inflammatory cell to the site of injury to clear the
Submission Date : 10-06-2016 Revision Date : 27-07-2016 Accepted Date : :24-08-2016

DOI: 10.5530/ijper.50.4.16 Correspondence: S. Sriram,

Centre for Advanced

Research in Indian System of Medicine (CARISM), SASTRA University, Thanjavur 613 401, Tamil Nadu, INDIA. Phone no: 9894091395 E-mail: sridharan.ram@ gmail.com

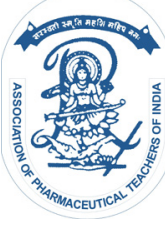

www.ijper.org 
offending trigger ${ }^{4}$ and is followed by an anti-inflammatory phase, in which resident tissue cells may acquire the potential for protecting themselves from further activation and injury. The inflammatory process protects our body from diseases by releasing cells and mediators that combat foreign substances and prevent infection. ${ }^{5}$ However when inflammations and inflammatory responses run unimpeded, it may prove to be a gateway for a number of diseases like arthritis, atherosclerosis, insulin resistance and cancer.

Inflammation is normally treated using steroids and non-steroidal anti-inflammatory drugs (NSAIDs). Although the therapeutic potential of these modern drugs are undisputable, the side effects they produce remains a major concern. Long-term administration of corticosteroids can cause hyperglycemia, insulin resistance, diabetes mellitus, osteoporosis and anxiety ${ }^{6}$ Patients who take NSAIDs have been found to have a 4 to 7 fold increased risk of developing gastric injuries ${ }^{7}$ that can range from nausea and dyspepsia to serious gastrointestinal (GI) complications such as peptic ulcerations complicated by bleeding or perforation ${ }^{8}$ leading to considerable morbidity and mortality. Phytomedicine research has a good chance of contributing new strategies through the development of new and better drugs for an evidence based and rational phytotherapy as it involves a multifaceted approach combining botanical, phytochemical, biological, and molecular techniques.' Though ancient medical treatises have documented a large number of medicinal plants, most have remained undocumented and uncharacterized, the knowledge of their use being passed down from generation to generation by word of mouth. Vernonia arborea Buch.-Ham. (Asteraceae) is one such important plant. Different species of Vernonia have been employed in traditional medicine for long in treatment for diabetes, ${ }^{10}$ inflammation, ${ }^{11}$ amoebic dysentery, ${ }^{12}$ gastrointestinal disorders, ${ }^{13}$ microbial and parasitic activities, ${ }^{14}$ Hepatotoxicities ${ }^{15}$ and cancer. ${ }^{16}$ Various parts of the plant Vernonia cinerea have been used as anti-malarial, astringent, anti-diarrhoeal and anti-viral agent. ${ }^{17}$ Literature evidences reveal that the root decoction and stem of $V$. cinerea have been used in the treatment of diabetes mellitus and human breast cancer. ${ }^{18,19}$ The bark juice of $V$. arborea is used for treating worms and chewed on the first signs of sprue in southern Sumatra. ${ }^{20}$ The plant also has a very good antifungal activity due to the presence of a sesquiterpene Zaluzanin D. ${ }^{21}$ Leaf juice is used to treat worms; decoction of bark in fever, leaf extract is also used for treating septic wounds, jaundice fever, wound healing and rheumatic pains.
Given the impressive medicinal potential of the genera and the plant, the present study is an attempt to evaluate the anti-inflammatory potential of $V$. arborea against formalin induced inflammation.

\section{MATERIALS AND METHODS}

\section{Plant material}

Fresh leaves of $V$. arborea Buch.-Ham. were collected from Kolli Hills, Eastern Ghats, Tamilnadu, India. The botanical identity of the plant was confirmed and authenticated by Prof. Dr. P. Jayaraman, Director, Institute of Herbal Botany, Plant Anatomy Research Centre, Tambaram, Chennai, Tamilnadu, India and a voucher specimen was deposited (Voucher No. PARC/2012/1239).

\section{Preparation of plant extract}

The plant material (Leaf) was shade dried and coarsely powdered. About $500 \mathrm{~g}$ of plant material was soaked in ethanol for $48 \mathrm{~h}$. After $48 \mathrm{~h}$ of soaking the solvent was distilled off under reduced pressure and dried in vacuum condition.

\section{Experimental animals}

Healthy adult Swiss albino male rats, two to three months old and weighing 150-220 g were obtained from Tamilnadu Veterinary and Animal Sciences University, Chennai, Tamilnadu. Animals were housed in standard polypropylene cages and were maintained under standard condition of 12:12 hrs. light/dark cycle and at an ambient temperature at $23 \pm 2{ }^{\circ} \mathrm{C}$, with $65 \pm 5 \%$ humidity. Animals were fed with standard rat chow pellet obtained from Sai Durga foods and feeds, Bangalore, India and water ad libitum. All the studies were conducted according to the ethical guidelines of CPCSEA after obtaining necessary clearance from Institutional Animal Ethical Committee (Approval No: 790/03/ac/CPCSEA).

\section{Experimental design}

Inflammation in experimental models was induced by formalin $(0.1 \mathrm{ml} / \mathrm{kg}$ bw. $)$ method. Rats were divided into 6 groups and treated accordingly. Rats in Group 3, 4 and 5 were pretreated with ethanolic leaf extract of V.arborea at increasing doses of 100, 200 and 300 $\mathrm{mg} / \mathrm{kg}$ bw. once daily at 24 hours' time interval. The pretreatment was done to study the protective effect of the ethanolic leaf extract of $V$. arborea against formalin induced inflammation.

Group 1: Normal male albino wistar rats.

Group 2: Received sub-plantar injection of $0.1 \mathrm{ml} / \mathrm{kg}$ bw. of formalin. 
Group 3: Pretreated with ethanolic leaf extract of V.arborea (100 mg/kg bw.) (Single dosage of formalin on $30^{\text {th }}$ day).

Group 4: Pretreated with ethanolic leaf extract of V.arborea (200 mg/kg bw.) (Single dosage of formalin on $30^{\text {th }}$ day).

Group 5: Pretreated with ethanolic leaf extract of V.arborea (300 mg/kg bw.) (Single dosage of formalin on $30^{\text {th }}$ day).

Group 6: Treated with formalin + standard drug indomethacin $(25 \mathrm{mg} / \mathrm{kg}$ bw.)

\section{Measurement of paw edema}

The increase in paw edema was measured by Vernier caliper method.22 The paw thickness was measured before and 6 days after induction of inflammation by using Vernier caliper. The difference in paw thickness after and before induction of inflammation was calculated and presented as mean increase in paw thickness ( $\mathrm{mm}$ ). The ability of anti-inflammatory drug to suppress paw inflammation was expressed as a percentage of inhibition of paw edema (Duffy et al. 2001) and this percentage can be calculated according to the following equation:

\section{Percentage of inhibition $(\%)=100 \times(1-\mathrm{X} / \mathrm{Y})$}

Where $\mathrm{X}=$ mean increase in paw volume, thickness or weight of treated rats

$\mathrm{Y}=$ mean increase in paw volume, thickness or weight of control rats.

\section{Assay of Antioxidant profile}

\section{Determination of Reduced glutathione ${ }^{23}$}

To $1 \mathrm{ml}$ of homogenate/blood, precipitated $1 \mathrm{ml}$ of TCA and the precipitate was removed by centrifugation. To $5 \mathrm{ml}$ of the supernatant, added $2 \mathrm{ml}$ of DTNB and the total volume was made up to $3 \mathrm{ml}$ with phosphate buffer. The absorbance was read spectrophotometrically at $412 \mathrm{~nm}$.

\section{Assay of glutathione peroxidase ${ }^{24}$}

The reaction mixture consisted of $0.2 \mathrm{ml}$ each of EDTA, sodium azide, $\mathrm{H}_{2} \mathrm{O}_{2}, \quad 0.4$ $\mathrm{ml}$ phosphate buffer and $0.1 \mathrm{ml}$ tissue homogenate. The mixture was incubated at $37^{\circ} \mathrm{C}$ at different time intervals. The reaction was arrested by addition of $0.5 \mathrm{ml}$ of TCA and the tubes were centrifuged at $2000 \mathrm{rpm}$. To $0.5 \mathrm{ml}$ of supernatant, $4 \mathrm{ml}$ of disodium hydrogen phosphate and $0.5 \mathrm{ml}$ of DTNB were added and the colour developed was read spectrophotometrically at $420 \mathrm{~nm}$ immediately.

\section{Assay of Super oxide dismutase ${ }^{25}$}

To the tubes containing $0.75 \mathrm{ml}$ ethanol and $0.15 \mathrm{ml}$ chloroform (chilled in ice), $0.1 \mathrm{ml}$ of tissue homogenate was added and centrifuged. To $0.5 \mathrm{ml}$ of supernatant, added $0.5 \mathrm{ml}$ EDTA solution and $1 \mathrm{ml}$ of buffer. The reaction was initiated by the addition of $0.5 \mathrm{ml}$ of epinephrine and the increase in absorbance was measured spectrophotometrically at $480 \mathrm{~nm}$.

\section{Estimation of Lipid peroxides ${ }^{26}$}

To $4 \mathrm{ml}$ of $0.85 \mathrm{~N} \mathrm{H}_{2} \mathrm{SO}_{4}, 0.1 \mathrm{ml}$ of homogenated tissue was added and mixed gently followed by $0.5 \mathrm{ml}$ of phosphotungstic acid and stirred well. The contents were centrifuged for $10 \mathrm{~min}$. The supernatant was discarded and the sediment mixed with $2.0 \mathrm{ml}$ of N/12 $\mathrm{H}_{2} \mathrm{SO}_{4}$ and $0.3 \mathrm{ml}$ of $10 \%$ phosphotungstic acid. The mixture was centrifuged for $10 \mathrm{~min}$. The sediment was suspended in $4.0 \mathrm{ml}$ of distilled water and $1 \mathrm{ml}$ of TBA reagent. The tubes were kept in a boiling water bath for $1 \mathrm{hr}$. After cooling $5 \mathrm{ml}$ of butanol was added to each tube and the colour extracted in the butanol phase was read spectrophotometrically at $532 \mathrm{~nm}$.

\section{Determination of Hemoglobin ${ }^{27}$}

A series of test tubes were taken and $0.02 \mathrm{ml}$ of blood was added to all the test tubes. Then $5 \mathrm{ml}$ of Drabkin's reagent was added to all the tubes and the test tubes were allowed to stand for 4 min. The blank was also treated similarly and read colorimetrically at $540 \mathrm{~nm}$.

\section{Enumeration of Red blood cells ${ }^{28}$}

The anticoagulated blood was sucked into the pipette up to the mark 0.5. It was diluted with RBC diluting fluid by sucking up to $11^{\text {th }}$ mark. The pipette was shaken for a minute and wiped away the excess of blood using blotting paper. Now placed a drop of blood at the edge of the cover slip which covers the counting chamber. The cells were counted under microscope on the 16 squares in 5 different parts of the fluid.

\section{Enumeration of Neutrophils, Eosinophils, Lymphocytes and Basophils by differential counting ${ }^{29}$}

A peripheral blood smear was made from a drop of blood on a microscope slide, which allowed the cells to be examined microscopically. Blood films were made by placing a drop of blood on one end of a slide, and using a spreader slide to disperse the blood over the slide's length. The slide was left to air dry, after which the blood was fixed to the slide by immersing it briefly in methanol. The fixative is essential for good staining and presentation of cellular detail. After fixation, the slide was stained using the May-Grunwald-Giemsa method to distinguish the cells from each other: the basophilic 
structures (which took up basic dyes) were colored in blue; theacidophilic or eosinophilic structures (which took up acid dyes) were colored in red whereas neutrophilic structures took up both dyes and were colored brownish purple which were observed microscopically.

\section{Enumeration of White blood cells ${ }^{28}$}

The anticoagulated blood was sucked into the pipette up to the mark 0.5. It was diluted with WBC diluting fluid by sucking up to $11^{\text {th }}$ mark. The pipette was shaken for minutes and wiped away the excess of blood using blotting paper. Now placed a drop of blood at the edge of the cover slip which covers the counting chamber. The cells were then counted under microscope on the 4 corner squares.

\section{Assay of marker enzymes}

\section{Estimation of Glutamate oxaloacetate transaminase $(G O T)^{30}$}

The assay mixture containing $1 \mathrm{ml}$ of substrate and $0.2 \mathrm{ml}$ of serum was incubated for $1 \mathrm{hr}$. at $37^{\circ} \mathrm{C}$. To the control tubes, serum was added after arresting the reaction by adding of $1 \mathrm{ml}$ of DNPH. The tubes were kept at room temperature for $30 \mathrm{~min}$. Added $0.5 \mathrm{ml}$ of $\mathrm{NaOH}$ and the colour developed was read at $540 \mathrm{~nm}$.

\section{Estimation of Glutamate pyruvate transaminase (GPT) ${ }^{30}$}

The assay mixture containing $1 \mathrm{ml}$ of substrate and $0.2 \mathrm{ml}$ of serum was incubated for $1 \mathrm{hr}$. at $37^{\circ} \mathrm{C}$. Added $1 \mathrm{ml}$ of DNPH and kept at room temperature for $20 \mathrm{~min}$. Serum was added to the control tubes after the reaction was arrested by the addition of $1 \mathrm{ml}$ of DNPH. Added $5 \mathrm{ml}$ of $\mathrm{NaOH}$ and the colour developed was read at $540 \mathrm{~nm}$.

\section{Estimation of Serum alkaline phosphatase $(A L P)^{30}$}

The reaction mixture containing $1.5 \mathrm{ml}$ carbonate buffer, $1 \mathrm{ml}$ di sodium phenyl phosphate, $0.1 \mathrm{ml}$ magnesium chloride and $0.1 \mathrm{ml}$ of serum was incubated at $37^{\circ} \mathrm{C}$ for $15 \mathrm{~min}$. The reaction was arrested by the addition of Folin's phenol reagent. Control tubes were also treated similarly but serum was added after the reaction was arrested with Folin's phenol reagent. Added $1 \mathrm{ml}$ of sodium carbonate. The colour developed was read after $10 \mathrm{~min}$ at $640 \mathrm{~nm}$.

\section{Estimation of Creatine kinase $^{31}$}

The incubation mixture containing $1.0 \mathrm{ml}$ of double distilled water, $0.1 \mathrm{ml}$ of serum, $0.1 \mathrm{ml}$ of ATP solution, $0.1 \mathrm{ml}$ of magnesium - cysteine reagent and $0.1 \mathrm{ml}$ of creatine was incubated at $37^{\circ} \mathrm{C}$ for $20 \mathrm{~min}$. The tubes were centrifuged and the supernatant was used for the estimation of phosphorous.

Statistical Analysis: All the results were expressed as mean \pm Standard Error of Mean (S.E.M). The data were statistically analyzed by one-way analysis of variance (ANOVA). P values $<0.05$ were considered as significant.

\section{RESULTS}

Effect of ethanolic leaf extract of $V$. arborea on paw thickness

Sub-cutaneous injection of diluted formalin into the hind paw elicited a biphasic pattern of pain-related behaviors, an early short-lasting neurogenic phase followed by a second and more sustained inflammatory phase when compared with normal control groups. However, pretreatment with ethanolic leaf extract of V.arborea (ELEVA) showed a significant inhibition $(\mathrm{p} \leq 0.05)$ in the late phase of formalin induced pain in a dose dependent manner which was well comparable with the standard drug indomethacin (Table 1 and Figure 1).

\section{Effect of ethanolic leaf extract of $V$. arborea on the antioxidant status of the experimental models}

Formalin induced experimental animals showed a significant decrease $(\mathrm{p} \leq 0.05)$ in the levels of antioxidant enzymesand increase in the levels of lipid peroxide when compared with normal control groups indicating tissue damage. Pretreatment with ELEVA resulted in a considerable increase in the enzymatic antioxidant values and decrease in the lipid peroxide levels when compared with the standard drug treated groups which are an indication of the anti-oxidant property of ELEVA (Table 2, 3; Figure 2a,2b, 2c and 3).

\section{Effect of ethanolic leaf extract of V.arborea on Hb, RBC and total WBC levels}

Decreased levels of hemoglobin and red blood cells were observed in formalin induced experimental rats when compared with normal control groups, which however on pretreatment with ELEVA in a dose dependent manner showed good progress which was well comparable with the standard drug treated rats (Table 4; Figure $4 \mathrm{a}, 4 \mathrm{~b}$ and $4 \mathrm{c})$. Similar results were observed in white blood cell levels.

\section{Effect of ethanolic leaf extract of V.arborea on neutrophils, lymphocytes, eosinophils and basophil levels}

A significant increase $(\mathrm{p} \leq 0.05)$ in the levels of neutrophils, lymphocytes, eosinophils and basophils were observed in formalin induced experimental animals when compared with normal control groups. However 


\section{Table 1: Effect of ethanolic leaf extract of $V$. arborea on} Paw thickness

\begin{tabular}{|c|c|}
\hline Groups & Paw thickness $\mathbf{( \mathbf { c m } ^ { 2 } )}$ \\
\hline I & $0.93 \pm 1.30^{*}$ \\
\hline II & $1.61 \pm 1.22^{* * *, a}$ \\
\hline III & $1.29 \pm 0.01$ \\
\hline IV & $1.10 \pm 0.02$ \\
\hline V & $0.94 \pm 0.03^{* *, a, b}$ \\
\hline VI & $0.93 \pm 0.36^{\mathrm{a}, \mathrm{b}}$ \\
\hline
\end{tabular}

*-Significant when compared between Group 1 and Group 2 ( $p \leq 0.05, n=6$ )

**-Significant when compared between Group 2 and Group $5(p \leq 0.05, n=6)$

a - Significant when compared between Group 2, Group 5 and Group $6(p \leq 0.05, n=6)$

b -Non significant when compared between Group 5 and Group $6(p \leq 0.01, n=6)$

\section{Table 2: Effect of ethanolic leaf extract of $V$. arborea on the levels of antioxidant enzymes}

\begin{tabular}{|l}
\hline Gro \\
\hline \\
\hline \\
\hline \\
\hline \\
\hline
\end{tabular}

\section{Groups}

\section{Reduced} glutathione ( $\mu \mathrm{g} / \mathrm{g}$ tissue)

\section{Glutathione} peroxidase ( $\mu$ moles of GSH oxidized $/ \mathrm{min} / \mathrm{g}$ tissue)

$50.51 \pm 0.05$

$50.51 \pm 0.05^{*}$
$12.60 \pm 0.04^{* * *,}$ a

IV $\quad 15.41 \pm 0.04$

\begin{tabular}{l|l}
$\mathrm{V}$ & $17.40 \pm 0.04^{* *}, \mathrm{a}, \mathrm{b}$
\end{tabular}

VI

$18.07 \pm 0.05^{a, b}$

* - Significant when compared between Group 1 and Group $2(p \leq 0.05, n=6)$

** - Significant when compared between Group 2 and Group 5 ( $p \leq 0.05, n=6)$

a - Significant when compared between Group 2, Group 5 and Group $6(p \leq 0.05, n=6)$

b - Non significant when compared between Group 5 and Group $6(p \leq 0.01, n=6)$

\section{Table 3: Effect of ethanolic leaf extract of $V$. arborea on LPO levels}

\begin{tabular}{|c|c|}
\hline Groups & $\begin{array}{c}\text { LPO } \\
\text { (nmoles of } \text { mda/g tissue) }\end{array}$ \\
\hline I & $215.41 \pm 2.40^{*}$ \\
\hline II & $636.21 \pm 1.58^{*, *, a}$ \\
\hline III & $574.25 \pm 1.48$ \\
\hline IV & $445.61 \pm 1.67$ \\
\hline V & $234.53 \pm 1.41^{* *, a, b}$ \\
\hline VI & $217.27 \pm 1.78^{\mathrm{a}, \mathrm{b}}$ \\
\hline
\end{tabular}

* - Significant when compared between Group 1 and Group 2 ( $p \leq 0.05, n=6)$

** - Significant when compared between Group 2 and Group $5(p \leq 0.05, n=6)$

a - Significant when compared between Group 2, Group 5 and Group 6 ( $p \leq 0.05, n=6)$

b - Non significant when compared between Group 5 and Group $6(p \leq 0.01, n=6)$

\section{Table 4: Effect of ethanolic leaf extract of $V$. arborea on $\mathrm{Hb}, \mathrm{RBC}$ and total WBC levels}

\begin{tabular}{|c|c|c|c|}
\hline Groups & $\mathrm{Hb}(\mathrm{g} \%)$ & $\begin{array}{c}\text { RBC } \\
\text { millions of cells } / \mathrm{mm}^{3}\end{array}$ & $\begin{array}{c}\text { Total WBC } \\
1000 \text { 's of cells } / \mathrm{mm}^{3}\end{array}$ \\
\hline I & $12.91 \pm 2.22^{*}$ & $5.47 \pm 0.14^{*}$ & $4.01 \pm 4.56^{*}$ \\
\hline II & $9.16 \pm 1.41^{*, * *}, a$ & $3.24 \pm 0.28^{*, * *, a}$ & $8.12 \pm 5.63^{* * * * a}$ \\
\hline III & $11.19 \pm 0.17$ & $4.47 \pm 0.08$ & $7.51 \pm 4.49$ \\
\hline IV & $12.07 \pm 0.25$ & $4.83 \pm 0.09$ & $5.70 \pm 2.86$ \\
\hline V & $12.87 \pm 0.08^{* *}, a, b$ & $5.32 \pm 0.11^{* *}, a, b$ & $4.44 \pm 2.86^{* *}, a, b$ \\
\hline VI & $13.38 \pm 0.27^{a, b}$ & $5.67 \pm 0.04 \mathrm{a,b}$ & $4.17 \pm 3.03^{a, b}$ \\
\hline
\end{tabular}

* - Significant when compared between Group 1 and Group 2 ( $p \leq 0.05, n=6)$

** - Significant when compared between Group 2 and Group $5(p \leq 0.05, n=6)$

a - Significant when compared between Group 2, Group 5 and Group $6(p \leq 0.05, n=6)$

b - Non significant when compared between Group 5 and Group $6(p \leq 0.01, n=6)$ 


\section{Table 5: Effect of ethanolic leaf extract of $V$. arborea on neutrophils, lymphocytes, eosinophil and} basophil levels

\begin{tabular}{|c|c|c|c|c|}
\hline Groups & $\begin{array}{c}\text { Neutrophils } \\
(\%)\end{array}$ & $\begin{array}{c}\text { Lymphocytes } \\
(\%)\end{array}$ & $\begin{array}{c}\text { Eosinophils } \\
(\%)\end{array}$ & $\begin{array}{c}\text { Basophils } \\
(\%)\end{array}$ \\
\hline I & $55.26 \pm 0.19^{*}$ & $40.20 \pm 0.07^{*}$ & $4.36 \pm 0.07^{*}$ & $1.16 \pm 0.06^{*}$ \\
\hline II & $76.41 \pm 1.77^{* * *}, a$ & $62.51 \pm 0.19^{*, * * a}$ & $8.73 \pm 0.08^{*, * *}, a$ & $4.18 \pm 0.07^{*, * *}, a$ \\
\hline III & $68.30 \pm 0.26$ & $57.38 \pm 0.22$ & $5.99 \pm 0.06$ & $3.19 \pm 0.06$ \\
\hline IV & $67.83 \pm 0.20$ & $53.01 \pm 0.03$ & $5.13 \pm 0.09$ & $2.73 \pm 0.08$ \\
\hline V & $63.30 \pm 0.17^{* *}, a, b$ & $51.03 \pm 0.15^{* *}, a, b$ & $3.88 \pm 0.09^{* *}, a, b$ & $1.98 \pm 0.09^{* *}, a, b$ \\
\hline VI & $50.23 \pm 0.32 \mathrm{a}, \mathrm{b}$ & $49.13 \pm 0.05^{a, b}$ & $3.21 \pm 0.06^{a, b}$ & $1.51 \pm 0.06^{a, b}$ \\
\hline
\end{tabular}

* - Significant when compared between Group 1 and Group 2 ( $p \leq 0.05, n=6)$

** - Significant when compared between Group 2 and Group $5(p \leq 0.05, n=6)$

a - Significant when compared between Group 2, Group 5 and Group $6(p \leq 0.05, n=6)$

b - Non significant when compared between Group 5 and Group $6(p \leq 0.01, n=6)$

Table 6: Effect of ethanolic leaf extract of $V$. arborea on SGOT, SGPT, ALP and CK levels

\begin{tabular}{|c|c|c|c|c|}
\hline Groups & SGOT (IU/L) & SGPT (IU/L) & ALP (IU/L) & $\begin{array}{c}\text { Creatine kinase } \\
\text { (IU/L) }\end{array}$ \\
\hline 1 & $37.23 \pm 1.57^{*}$ & $33.96 \pm 1.41^{*}$ & $99.89 \pm 1.67^{*}$ & $270.56 \pm 1.74^{*}$ \\
\hline II & $88.47 \pm 1.97^{*, * *}$, a & $77.98 \pm 1.87^{*, *}$, a & $225.67 \pm 1.35^{*, * * a}$ & $474.89 \pm 1.88^{*, * *}, a$ \\
\hline III & $76.89 \pm 1.45$ & $71.87 \pm 1.67$ & $198.81 \pm 1.76$ & $387.76 \pm 1.76$ \\
\hline IV & $68.94 \pm 1.54$ & $53.66 \pm 1.77$ & $182.32 \pm 1.67$ & $318.71 \pm 1.42$ \\
\hline V & $57.68 \pm 1.67^{* *}, a, b$ & $45.54 \pm 1.47^{* *}, a, b$ & $139.43 \pm 1.88^{* *}, \mathrm{a}, \mathrm{b}$ & $274.56 \pm 1.68^{* *}, a, b$ \\
\hline VI & $38.45 \pm 1.48^{\mathrm{a}, \mathrm{b}}$ & $32.34 \pm 1.49 \mathrm{a}, \mathrm{b}$ & $114.85 \pm 1.56^{\mathrm{a}, \mathrm{b}}$ & $228.45 \pm 1.59^{a, b}$ \\
\hline
\end{tabular}

* - Significant when compared between Group 1 and Group 2 ( $p \leq 0.05, n=6)$

** - Significant when compared between Group 2 and Group $5(p \leq 0.05, n=6)$

a - Significant when compared between Group2, Group 5 and Group $6(p \leq 0.05, n=6)$

b - Non significant when compared between Group 5 and Group $6(p \leq 0.01, n=6)$

there was a reduction in the population of neutrophils, eosinophils, lymphocytes and basophils in experimental rats pretreated with ELEVA which was well comparable with the standard drug treated groups (Table 5; Figure 5a, $5 b, 5 c$ and $5 d)$.

\section{Effect of ethanolic leaf extract of V.arborea on serum marker enzyme levels}

Increased levels of SGOT, SGPT and ALP were observed in formalin induced animals when compared with normal control groups which subsequently showed a significant decrease $(\mathrm{p} \leq 0.05)$ on dose dependent pretreatment with ELEVA which was well comparable with the standard drug treated groups indicating inhibition of inflammation. Creatine kinase, was found to be increased in formalin induced groups but was subsequently decreased on pretreatment with ELEVA at dose levels of $100,200,300 \mathrm{mg} / \mathrm{kg}$ bw. whose effect was on par with the standard drug treated groups (Table 6; Figure $6 a, 6 b, 6 c$ and $6 d$ ).

\section{DISCUSSION}

Formalin-induced experimental models produce a distinct biphasic nociception in the paw, a first phase (lasting the first $5 \mathrm{~min}$ ) corresponding to acute neurogenic pain, and a second phase (lasting from 15 to $30 \mathrm{~min}$ ) corresponding to inflammatory pain responses. ${ }^{32}$ In the present study, notable edema and inflammation was observed in the experimental animals. Edema formation in the paw is the result of a synergism between various inflammatory mediators that increased vascular permeability and blood flow. ${ }^{33}$ However, pretreatment with ELEVA extracts showed a significant inhibition in the late phase of formalin induced pain in a dose dependent manner which was well comparable with the standard drug indomethacin and also corroborates with the findings of Young et al. (2005). ${ }^{34}$

Recently, it has been shown that faulty cellular antioxidant systems cause organisms to develop a series of inflammatory and cancer diseases..$^{35}$ The present study also demonstrated a cumulative decrease in the levels of antioxidant enzymes and considerable increase in the levels 


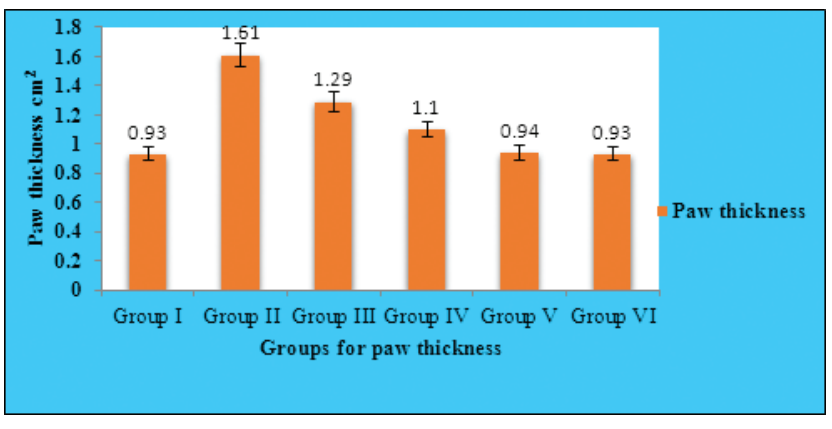

Figure 1: Effect of ethanolic leaf extract of $V$. arborea on paw thickness

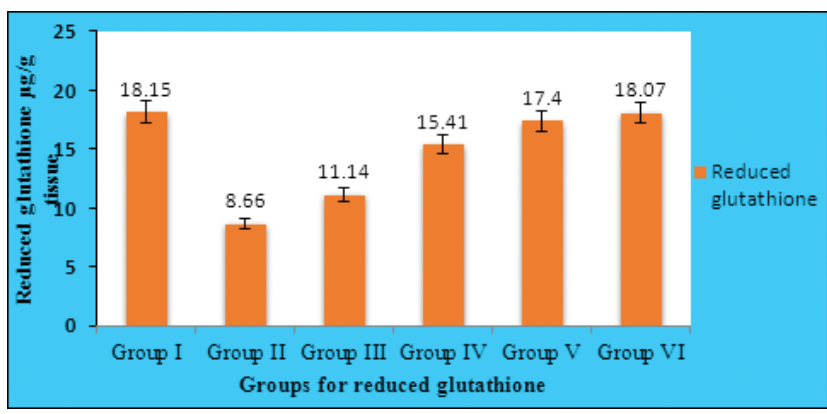

Figure 2a: Effect of ethanolic leaf extract of $V$. arborea on reduced glutathione levels

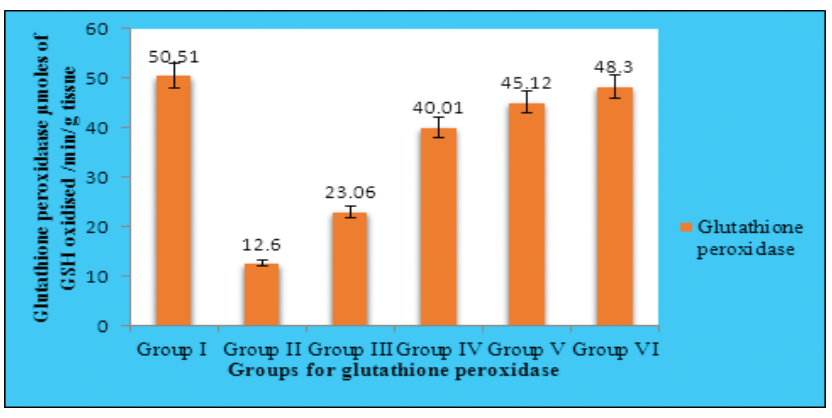

Figure 2b: Effect of ethanolic leaf extract of $V$. arborea on GPx levels.

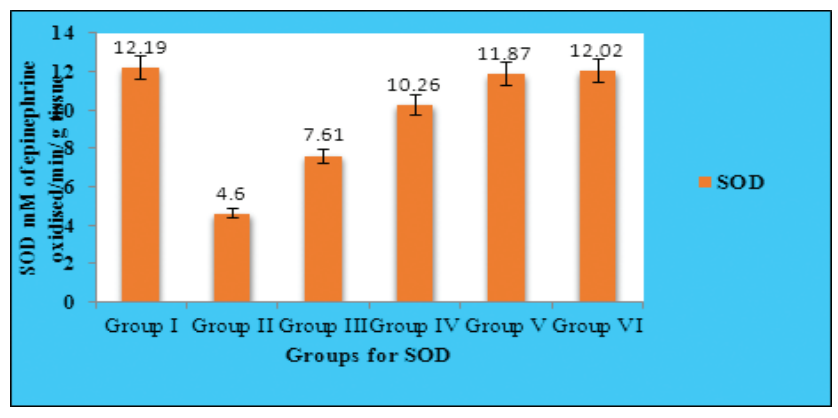

Figure 2c: Effect of ethanolic leaf extract of $V$. arborea on SOD levels.

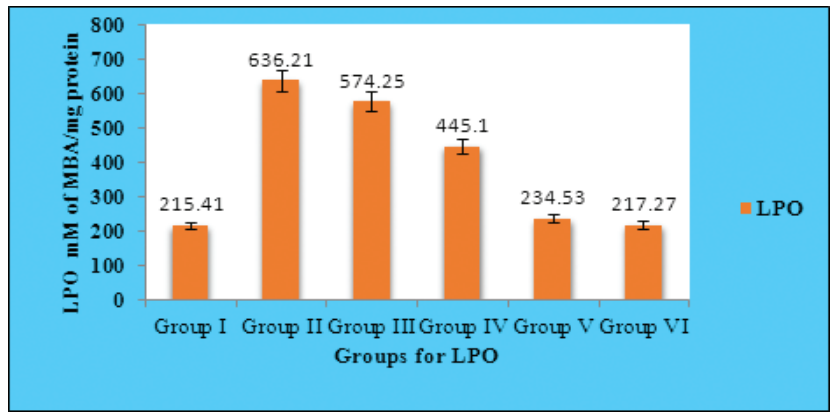

Figure 3: Effect of ethanolic leaf extract of $V$. arborea on LPO levels.

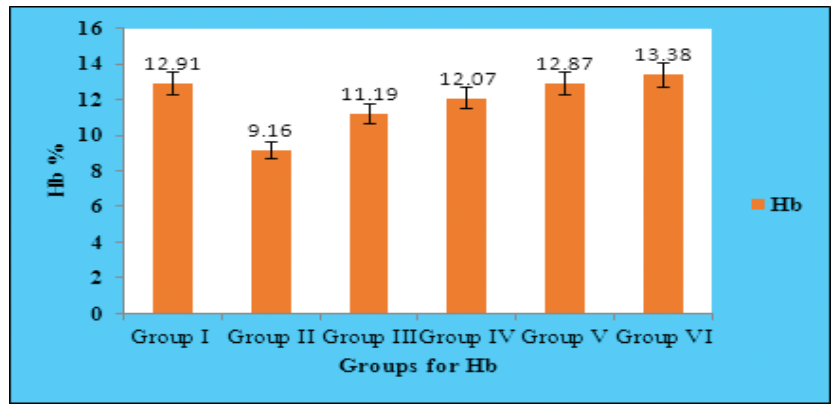

Figure 4a: Effect of ethanolic leaf extract of $V$. arborea on $\mathrm{Hb}$ levels.

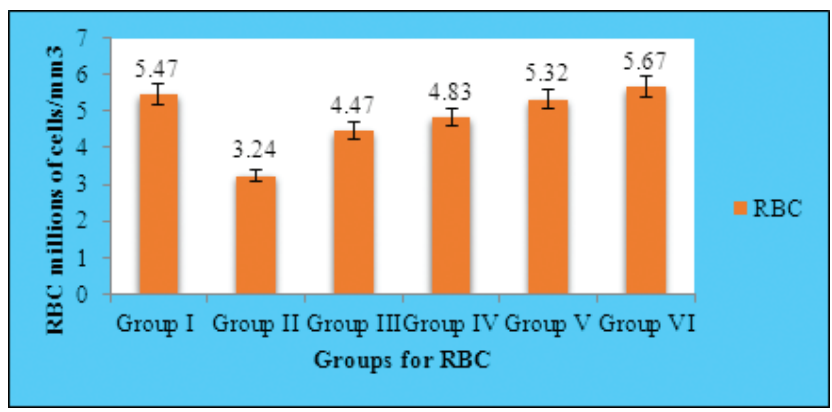

Figure 4b: Effect of ethanolic leaf extract of $V$. arborea on RBC levels.

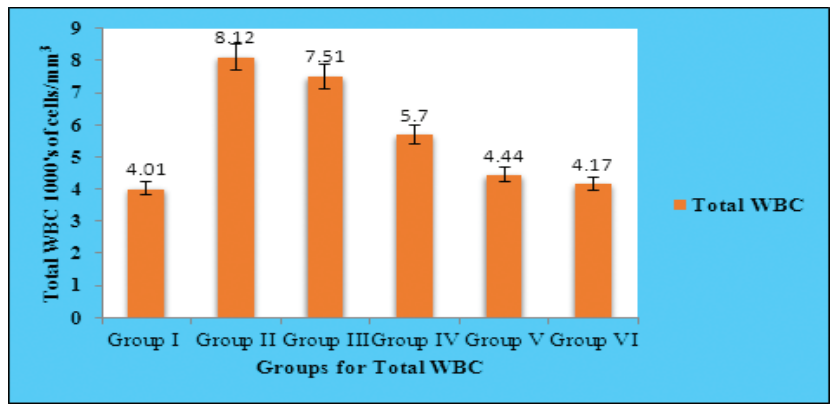

Figure 4c: Effect of ethanolic leaf extract of $V$. arborea on total WBC levels. 


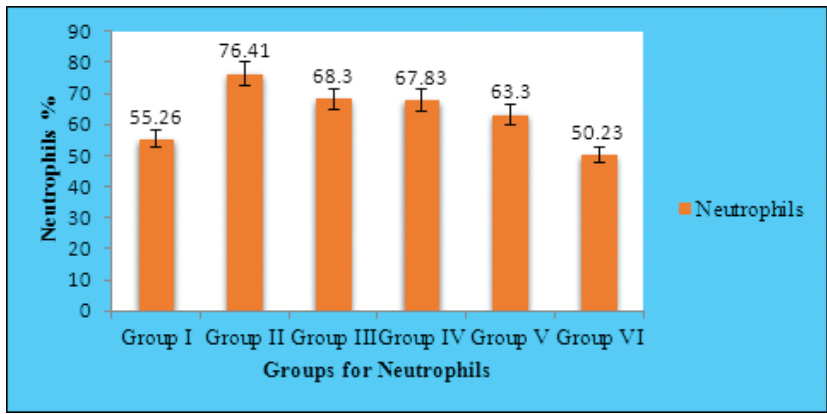

Figure 5a: Effect ofethanolic leaf extract on V. arborea on neutrophil levels.

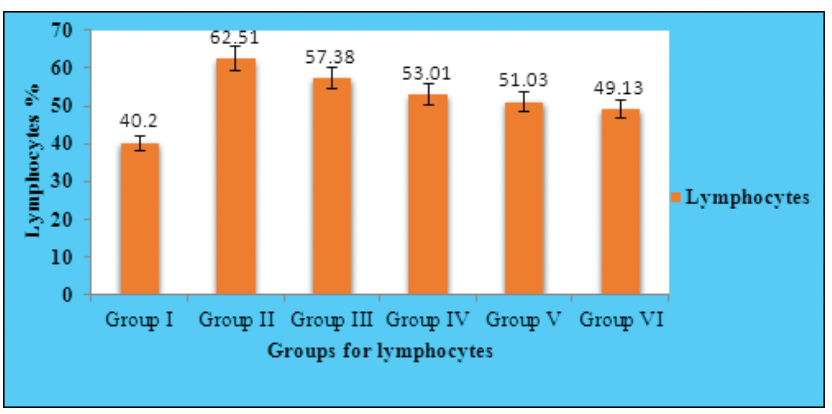

Figure 5b: Effect of ethanolic leaf extract of $V$. arborea on lymphocyte levels.

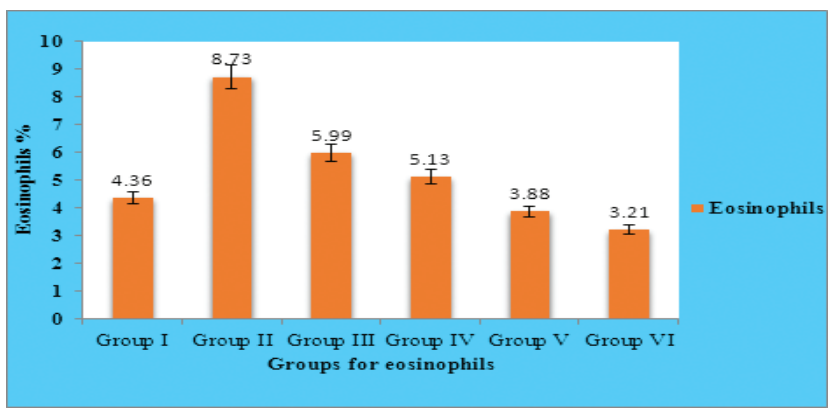

Figure 5c: Effect of ethanoli leaf extract of $V$. arborea on eosinophil levels.

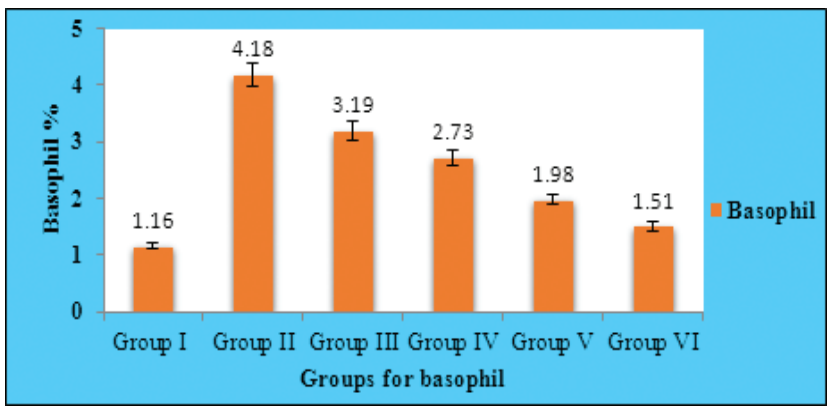

Figure 5d: Effect of ethanolic leaf extract of $V$. arborea on basophil levels.

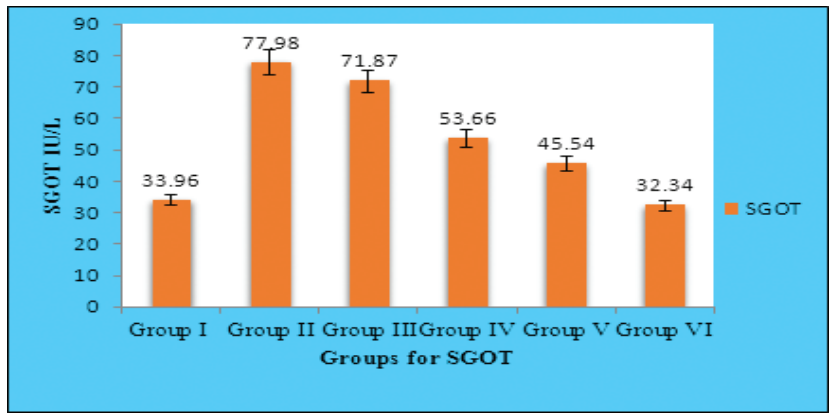

Figure 6a: Effect of ethanolic leaf extract of $V$. arborea on SGOT levels.

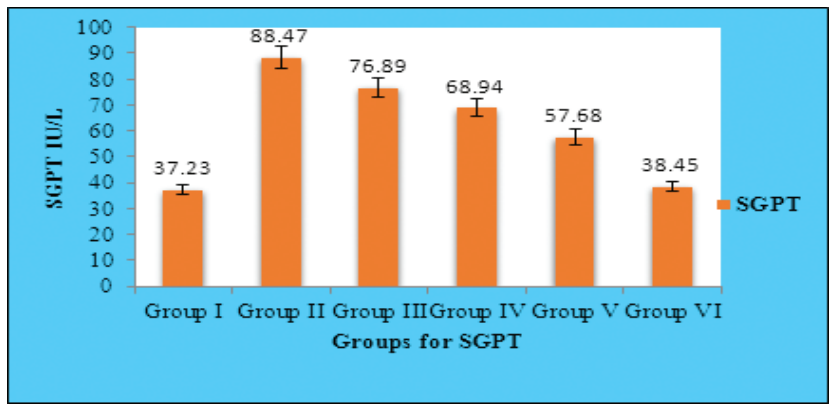

Figure 6b: Effect of ethanolic leaf extract of $V$. arborea on SGPT levels.

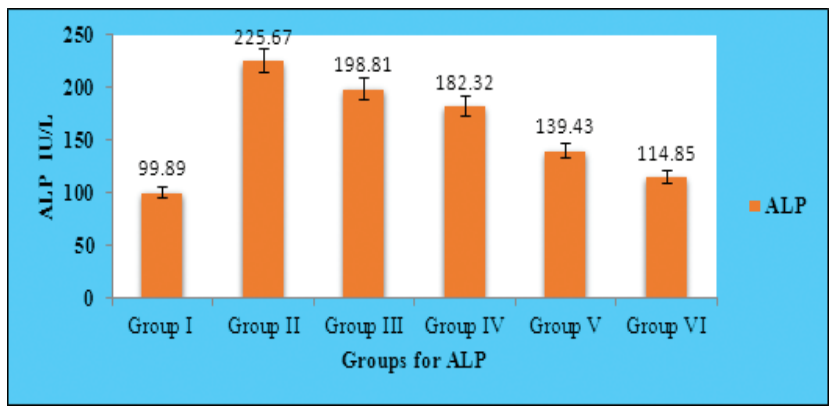

Figure 6c: Effect of ethanolic leaf extract of $V$. arboreaon ALP levels.

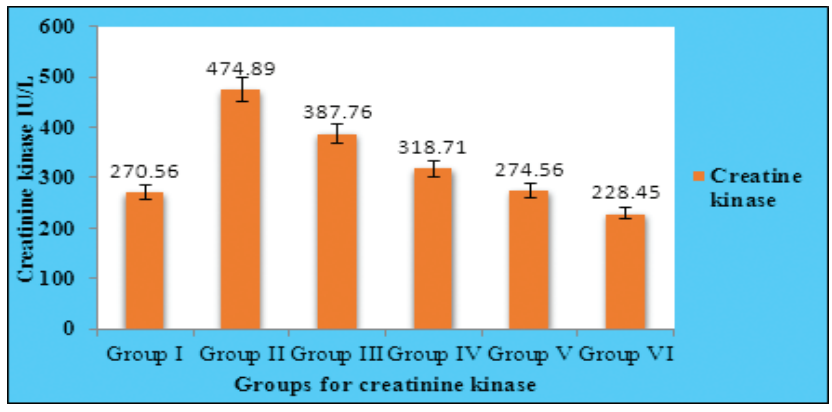

Figure 6d: Effect of ethanolic leaf extract on V. arborea on creatine kinase levels. 
of lipid peroxide which is well indicative of tissue damage on induction of formalin in experimental animals. However pretreatment with ELEVA extracts resumed the levels of antioxidants to normalcy accompanied with a notable decrease in the lipid peroxide levels. The results showed a significant increase in the enzymatic antioxidant values at a maximal dose of $300 \mathrm{mg} / \mathrm{kg}$ bw. which was on par with the standard drug indomethacin. Cytokines produced by neutrophils are good indicators of progressive inflammation as neutrophils are important sources of free radicals at the site of inflammation. ${ }^{36} \mathrm{~A}$ notable increase in the population of neutrophils in the present study was suggestive of propagation of inflammation which however was well reduced and reverted close to normalcy in groups pretreated with ELEVA with increasing concentrations. Eosinophils are granulated molecules that release lipid derived mediators which stimulate responses in tissues which is indicative of inflammation. The present investigation showed an elevated level in their count indicative of the release of cytokines and interleukins in formalin induced experimental animals accounting to inflammation. However the pretreated groups showed a good reduction in the population of eosinophils that indicate restoration of normal tissues. Lymphocyte is the predominant cell in chronic inflammation. Elevated levels of lymphocytes were observed in formalin induced experimental rats indicative of tissue damage which was reversed in pretreated groups. Basophils appear increased in many specific kinds of inflammatory reactions, particularly those that cause allergic symptoms ${ }^{37}$ and were found to be in high numbers in the formalin induced groups in the present study. However the pretreated groups showed a good reduction in the population of basophils. Anemia is a normal pathological condition notable in inflammation due to deprived oxygen supply to the damaged tissue. Hemoglobin and RBC play a major role in the oxygen transport whose levels were clearly observed in decreased amounts in the formalin induced experimental animals. Such a condition was also reported by Swingle \& Shideman (1972). ${ }^{38}$ However, pretreatment with the ELEVA at increasing dose levels brought back these levels to near normalcy which was on par with the standard drug treated groups.

Total WBC plays a major role in body's defense mechanism and may increase during inflammation due to the release of interleukins. ${ }^{39}$ In the present study, the level of WBC was found to be higher in formalin induced experimental animals. Pretreatment with EEVA at the dose levels of 100, 200, $300 \mathrm{mg} / \mathrm{kg}$ bw. Significantly reduced the WBC count indicating substantial recovery from the inflammatory process.
There is increasing evidence that lysosomal enzymes like SGOT, SGPT and ALP play an important role in the development of acute and chronic inflammation. ${ }^{40}$ In the present study, pretreatment with ELEVA at dose levels of $100,200,300 \mathrm{mg} / \mathrm{kg}$ bw. decreased the levels of SGOT, SGPT, and ALP that were previously found to be increased in formalin induced experimental animals. Biochemical enzymes such as Creatine kinase are wellestablished biomarkers that are often released upon cellular degeneration such as necrosis and inflammation. ${ }^{41}$ Increase in Creatine kinase concentrations are related to the irreversible injury which was also well observed in the present investigation in experimental animals after formalin induction which on pretreatment with ELEVA in a dose dependent manner showed reversion to normalcy.

\section{CONCLUSION}

The results obtained from the present study show promising signs about the anti-inflammatory potential of the ethanol leaf extract of $V$. arborea against formalin induced inflammation. The extract exhibits appreciable anti-inflammatory activity at a dosage of $300 \mathrm{mg} / \mathrm{kg}$ b.w. The next course of study would be to identify and isolate the anti-inflammatory active principles of this plant, evaluate their anti-inflammatory effect and to decipher the mechanism of action involved.

\section{ACKNOWLEDGEMENT}

The authors are thankful to Nehru Memorial College and SASTRA University for providing the necessary infrastructure and facility to carry out this research work.

\section{CONFLICT OF INTEREST}

Authors declare no conflict of interest.

\section{ABBREVIATIONS USED}

NSAIDs: Non-steroidal anti-inflammatory drugs; DTNB: 5-5'-dithio-bis-(2-nitrobenzoic acid); EDTA: Ethylenediaminetetraacetic acid; TBA: thiobarbituric acid; RBC: Red Blood Cells; WBC: White Blood Cells; SGOT: Serum Glutamate oxaloacetate transaminase; SGPT: Serum Glutamate pyruvate transaminase; ALP: Alkaline Phosphatase; ELEVA: Ethanolic leaf extract of V.arborea; Hb: Hemoglobin.

\section{REFERENCES}


1. Nathan C. Points of control in inflammation. Nature. 2002;420(6917):846-52. http://dx.doi.org/10.1038/nature01320 ; PMid:12490957

2. Vodovotz Y Csete M, Bartels J, Chang S, An G. Translational systemsbiology of inflammation. PLOS Computational Biology. 2008;4:1-6. http://dx.doi. org/10.1371/journal.pcbi.1000014 ; PMid:18437239 PMCid:PMC2329781

3. Henson PM, Murphy RC. Mediators of the inflammatory process. Amsterdam: Elsevier; 1989.

4. Huwiler A, Pfeilschifter J. Lipids as targets for novel anti-inflammatory therapies. Pharmacol. Ther. 2009;124(1):96-112. http://dx.doi.org/10.1016/j. pharmthera.2009.06.008; PMid:19576246

5. El-Gamal MI, Bayomi SM, El-Ashry SM, Said SA, Abdel-Aziz AA, AbdelAziz NI. Synthesis and anti-inflammatory activity of novel (substituted) benzylidene acetone oxime ether derivatives: molecular modeling study. European Journal of Medicinal Chemistry. 2010;45(4):1403-14. http://dx.doi. org/10.1016/j.ejmech.2009.12.041; PMid:20079558

6. Donihi AC, Raval D, Saul M, Korytkowski, MT, DeVita MA. Prevalence and predictors of corticosteroid-related hyperglycemia in hospitalized patients. Endocr Pract. 2006;12(4):358-362. http://dx.doi.org/10.4158/EP.12.4.358; PMid:16901792

7. Lanas A, Rodrigo L, Marquez J, Bajador E, Perez-Roldan F, Cabrol J et al. Low frequency of upper gastrointestinal complications in a cohort of high risk patients taking low-dose aspirin or NSAIDS and omeprazole. Scand J Gastroenterol. 2003;38(7):693-700. http://dx.doi. org/10.1080/00365520310003967 ; PMid:12889553

8. Kasper MD, Dennis L, Braunwald E, Fauci MD, Anthony S, Hauser MD et al. Harrison's principles of internal medicine. McGraw-Hill. 2005;16:12-34.

9. Croteau, R, Kutchan TM, Lewis NG. Natural products (secondary metabolites). In: Buchanan, B, Gruissem W, Jones R. Biochemistry and Molecular Biology of Plants, American Society of Plant Physiologists, Rockville, MD, USA: 2000;24:1250-319.

10. Akah PA, Okafor CL. Blood sugar lowering effects of $V$. amygdalina Del in an experimental rabbit model. Phytother Res. 1992;6(3):171-3. http://dx.doi. org/10.1002/ptr.2650060318

11. George U, will O, George O, will A. Evaluation of anti-inflammatory activity of extract of Vernoniaamygdalina. East J Med. 2009;14:20-2.

12. Moundipa PF, Kamini G, Flore M, BilongBilong CF, Bruchhaus I. Invitroamoebicidal activity of some medicinal plants of the Bamun region (Cameroon). African J Trad CAM. 2005;2(2):113-21.

13. Akah PA, Ekekwe RK. Ethnopharmacology of some of the Asteraceae family used in the Nigerian traditional medicine. Fitoterapia. 1995;66(4):352-5.

14. Akinpelu DA. Antimicrobial activity of Vernoniaamygdalinaleaves. Fitoterapia. 1999;70(4):432-4. http://dx.doi.org/10.1016/S0367-326X(99)00061-1

15. Iwalokun BA, Efedede BU, Alabi-Sofunde JA, Oduala T, Magbagveola OA, Akinwande Al. Hepatoprotective and antioxidant activities of Vernoniaamygdalina on acetaminophen-induced hepatic damage in mice. J Med Food. 2006;9(4):524-30. http://dx.doi.org/10.1089/jmf.2006.9.524 ; PMid: 17201640

16. Kupchan SM, Hemingway RJ, Karim A, Werner D. Tumor inhibitors. XLVII. Vernodalin and Vernomygdin, two new cytotoxic sesquiterpene lactones from Vernoniaamygdalina Del. J Org Chem. 1969;34(12):3908-11. http://dx.doi. org/10.1021/jo01264a035; PMid:5357533

17. Dalmeida E, Daffodil, Lincy P, Mohan VR. Study of whole plant of Vernonia cinereaLESS. For in vitro antioxidant activity. Int J Pharm. 2014;4(2):172-8.

18. Mishra AS. J. crude res. 1984;123:1012-28

19. Yao-haurkuo, Yu-Jenkuo, Ang-Suyu, Ming-Derwu. Chem Pharmaceu Bull. 2003;51:425. http://dx.doi.org/10.1248/cpb.51.425

20. Gamble JS. Flora of the Presidency of Madras, Botanical Survey of India, Calcutta: 1936.
21. Pradhan D, Panda PK, Tripathy G. Wound healing activity of aqueous and methanolic bark extracts of VernoniaarboreaBuch.-Ham in wistar rats. Nat prod Radiance. 2009;8(1):6-11.

22. Joseph SM, George MC, Nair JR. Effect of feeding cuttlefish liver oil on immune function, inflammatory response and platelet aggregation in rats. Current Sci. 2005;88(3):507-10.

23. Beutler E, Duron C, Kelly BM. Improved method for the determination of blood glutathione. J Lab Clin Med. 1963;65:782-97.

24. Rotruck JT, Pope AL, Ganther H, Swanson AB, Hafeman DG, Hoeksira WG. Selenium: Biochemical role as a component of glutathione peroxidase. Science. 1973;1790:588-90. http://dx.doi.org/10.1126/science.179.4073.588

25. Misra HP, Fridovich I. The role of superoxide anion in the auto-oxidation of epinephrine and a simple assay for SOD. J Biol Chem. 1972;247(10):3170-5. PMid: 4623845

26. Ohkawa $\mathrm{H}$, Ohishi $\mathrm{N}$, Yagi K. Assay of lipid peroxides in animal tissues for thiobarbituric acid reaction. Annual Biochem. 1979;95(2):351-8. http://dx.doi. org/10.1016/0003-2697(79)90738-3

27. Drabkin DL, Austin JM. Spectrophotometric constants for common hemoglobin derivatives in human, dog and rabbit blood. J Biol Chem. 1932;98(2):719-33.

28. Armour D, Blood FR, Belden DA. The manual for laboratory work in mammalian physiology. Chicago: The university of Chicago press. 1964;3:4-6.

29. Dacie J, Lewis S. Practical haematology. London: Churchill Livingstone; 1995;2:507-514. PMCid:PMC2397950

30. King J. In: Practical Clinical Enzymology. London: Princeton MJ(Fol) Van D Nostrand Company; 1965;363.

31. Okinaka S, Kumagi A, Ebashi S, Sugita H, Mornoi H, Toyokura Y. Serum Creatine Phosphokinase activity in progressive muscular dystrophy and neuromuscular disease. Arch - Neurol. 1961;4(5):520-5. http://dx.doi. org/10.1001/archneur.1961.00450110050006 ; PMid:13730599

32. Huang MH, Huang SS, Wang BS, Wu CH, Sheu MJ, Hou WC et al. Antioxidant and anti-inflammatory properties of Cardio spermum halicacabum and its reference compounds ex vivo and in vivo. J Ethnopharmacol. 2011a;133(2):743-50. http://dx.doi.org/10.1016/j.jep.2010.11.005; PMid:21073940

33. Lalenti A, Lanaro A, Moncada S, Di Rosa M. Modulation of acute inflammation by endogenous nitric oxide.Eur. J Pharmacol. 1995;211(2):177-84. http:// dx.doi.org/10.1016/0014-2999(92)90526-A

34. Young H, Luo Y, Cheng H, Hsieh W, Liao J, Peng W. Analgesic and antiinflammatory activities of Gingerol. J Ethanopharmacol. 2005;96(1):207-10. http://dx.doi.org/10.1016/j.jep.2004.09.009 ; PMid:15588672

35. Valko M, Rhodes CJ, Moncol J, Izakovic M, Mazur M. Free radicals, metals and anti-oxidants in oxidative stress-induced cancer. Chem Biol Interact. 2006;160:1-40. http://dx.doi.org/10.1016/j.cbi.2005.12.009 ; PMid:16430879

36. Goel RK, Sairam K, Rao CH, Raman. Role of gastric antioxidant and anti helicobacter pylori activities in the antiulcerogenic activity of banana. Indian J Exp Biol. 2001;39(7):719-22. PMid:12019769

37. John NAA, Shobana G. Anti-inflammatory activity of Talinumfruticosum L. on formalin induced paw edema in albino rats. J App Pharm Sci. 2012;02(01):123-7.

38. Swingle KF, Shideman FE. Phases of the inflammatory response to subcutaneous implantation of cotton pellet and their modification by certain anti-inflammatory agent. J Pharmacol Exp Ther. 1972;183(1):26-234.

39. Eric GB, Lawrence JL. Rheumatoid arthritis and its therapy: The text book of therapeutics drug and disease management. $16^{\text {th }}$ ed. Blatimore: Williams and Wilkins Company. 1996;579-95.

40. Anderson AJ, Bocklehurst WE, Wills AL. Evidence for the role of lysosomes in the formation of prostaglandins during carrageenan induced inflammation in rat. Pharmacol Res Comm. 1971;3(1):13-7.

41. Apple FS, Murakami M, Panteghini M. International survey on the use of cardiac markers. Clin Chem. 2001;47(3):587-8. PMid:11238317 


\section{SUMMARY}

- Vernonia arborea is a medicinal plant belonging to the Asteraceae family.

- Different species of Vernonia have been employed in traditional medicine for long in treatment for several ailments.

- Given the rich medicinal potential of this genus, the therapeutic properties of the plant $\mathrm{V}$. arborea is relatively less explored.

- The present study investigates the anti-oxidant and anti-inflammatory activity of V.arborea

- The results obtained are indicative of the appreciable anti-oxidant and anti-inflammatory potential of the plant.

\section{About Authors}

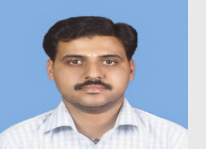

Dr.S.Sriram: Post Doctoral Fellow, Centre for Advanced Research in Indian System of Medicine (CARISM), SASTRA University, Thanjavur, Tamil Nadu, INDIA. 